\title{
Methyl-donor depletion of head and neck cancer cells in vitro establishes a less aggressive tumour cell phenotype
}

\author{
Vanessa Hearnden ${ }^{1,2} \cdot$ Hilary J. Powers ${ }^{1} \cdot$ Abeir Elmogassabi $^{1} \cdot$ Rosanna Lowe $^{1} \cdot$ \\ Craig Murdoch ${ }^{2} \mathbb{D}$
}

Received: 9 August 2016 / Accepted: 19 February 2017 / Published online: 1 March 2017

(C) The Author(s) 2017. This article is published with open access at Springerlink.com

\begin{abstract}
Purpose DNA methylation plays a fundamental role in the epigenetic control of carcinogenesis and is, in part, influenced by the availability of methyl donors obtained from the diet. In this study, we developed an in-vitro model to investigate whether methyl donor depletion affects the phenotype and gene expression in head and neck squamous cell carcinoma (HNSCC) cells.

Methods HNSCC cell lines (UD-SCC2 and UPCISCC72) were cultured in medium deficient in methionine, folate, and choline or methyl donor complete medium. Cell doubling-time, proliferation, migration, and apoptosis were analysed. The effects of methyl donor depletion on enzymes controlling DNA methylation and the pro-apoptotic factors death-associated protein kinase-1 (DAPK1) and p53 upregulated modulator of apoptosis (PUMA) were examined by quantitative-PCR or immunoblotting.

Results HNSCC cells cultured in methyl donor deplete conditions showed significantly increased cell doubling times, reduced cell proliferation, impaired cell migration, and a dose-dependent increase in apoptosis when compared to cells cultured in complete medium. Methyl donor depletion significantly increased the gene expression of DNMT3a and TET-1, an effect that was reversed
\end{abstract}

Electronic supplementary material The online version of this article (doi:10.1007/s00394-017-1411-5) contains supplementary material, which is available to authorized users.

Craig Murdoch

c.murdoch@sheffield.ac.uk

1 Human Nutrition Unit, Department of Oncology, University of Sheffield, Sheffield S10 2RX, UK

2 School of Clinical Dentistry, University of Sheffield, Sheffield S10 2TA, UK upon methyl donor repletion in UD-SCC2 cells. In addition, expression of DAPKI and PUMA was increased in UD-SCC2 cells cultured in methyl donor deplete compared to complete medium, possibly explaining the observed increase in apoptosis in these cells.

Conclusion Taken together, these data show that depleting HNSCC cells of methyl donors reduces the growth and mobility of HNSCC cells, while increasing rates of apoptosis, suggesting that a methyl donor depleted diet may significantly affect the growth of established HNSCC.

Keywords DNA methylation - Head and neck cancer · Methyl donor $\cdot$ Apoptosis $\cdot$ DAPK

\section{Introduction}

It is estimated that there were 140,000 new cases and 63,500 deaths from head and neck squamous cell carcinoma (HNSCC) in Europe in 2012 [1]. The 5-year agestandardised relative survival rate was approximately $40 \%$ for Europe overall with survival rates lowest in Eastern European and highest in Central, Western, and Northern European counties for all sub-categories of HNSCC such as oral cavity, oropharyngeal, laryngeal, and hypopharyngeal cancer [2]. Head and neck squamous cell carcinoma (HNSCC) is frequently (54\%) detected at an advanced stage and so often has a poor prognosis with less than $55 \%$ overall 5-year survival following diagnosis [2, 3]. HPV infection is responsible for virtually all cervical cancers and approximately $35 \%$ of diagnosed oropharyngeal cancers worldwide, although there is a significant region to region variation globally [4]. Chaturvedi et al. predict that the number of HPV-positive HNSCC cases will exceed cases of cervical cancer by 2020 , demonstrating the urgent need 
for a better understanding of the disease process and potential prevention strategies [5].

Folate is an essential dietary component required for the synthesis of nucleotides and for the synthesis and repair of DNA. There are several mechanisms by which folate status affects cancer risk. Low folate status has been shown to cause uracil mis-incorporation into DNA [6], cytogenetic damage [7], and impaired DNA repair [8] all of which increase the risk of neoplastic change. Indeed, epidemiological studies have shown that low dietary folate intake is associated with an increased risk of HNSCC carcinogenesis [9-11]. Conversely, other studies have shown that a high folate status may drive the growth of established tumours $[12,13]$. In addition, there is evidence that folate status affects HPV infection and behaviour. Studies by our group and others have shown that low folate status is associated with an increased risk of cervical HPV infection $[14,15]$ and cervical intraepithelial neoplasia or invasive cancer [15]. The direction of influence of folate status on HPV persistence is not clear [14, 15]. Recently, Xiao et al. showed that low folate conditions increased HPV integration into the keratinocyte host genome and reduced viral capsid production in human keratinocytes in vitro [16]. Folate and other diet-derived methyl donors (choline, betaine, methionine) may also influence cancer risk and progression through epigenetic effects. The epigenetic control of gene expression is regulated, in part, by the methylation of cytosine-guanine dinucleotides within gene promoter regions, and dysregulated methylation in the promoter sequences of tumour-suppressor or oncogenes can promote carcinogenesis in HNSCC [17, 18]. For the methylation of DNA, methyl groups are transferred from the ultimate methyl donor, $s$-adenosyl methionine (SAM), onto cytosine residues in DNA by DNA methyltransferases (DNMTs). Whilst the factors that regulate DNMTs are not well understood, there is evidence that methyl donor depletion may lower DNMT expression in cervical cancer cells enzymes. DNMT1 preferentially adds methyl groups to hemi-methylated DNA and is responsible for maintenance of DNA methylation following cell division [19]. DNMT3a and $3 \mathrm{~b}$ add methyl groups to $\mathrm{CpG}$ sites and are required for de novo DNA methylation [20]. In contrast, Tet methylcytosine dioxygenase 1 has been implicated in demethylation of DNA [21]. Poomipark et al. recently demonstrated methyl donor status altered the expression of DNMTs in cervical cancer cells [22]. Appropriate gene methylation is important for the regulation of many processes, including those involved in cancer progression such as cell cycle control and apoptosis. In addition, cell stress due to lack of essential nutrients may also lead to increased expression of key pro-apoptotic genes such as death-associated protein kinase-1 (DAPK1) [23] and p53 upregulated modulator of apoptosis (PUMA) [24], and so alterations in methyl donor availability may have profound effects on cell behaviour.

Here, we have developed an in vitro model of methyl donor-deficient HNSCC cells, with particular emphasis on HPV-positive HNSCC. We show, for the first time, that methyl donor deficiency significantly alters the phenotype of HNSCC cells by decreasing their proliferation and migratory capacity whilst up-regulating the expression of pro-apoptotic genes and increasing levels of apoptosis.

\section{Materials and methods}

\section{Cell culture and methyl donor depletion}

UD-SCC2 (HPV-positive) [25] and UPCI-SCC72 (HPVnegative) [26] cells were cultured in RPMI medium supplemented with $10 \%(\mathrm{v} / \mathrm{v})$ fetal bovine serum (FBS), $100 \mathrm{IU} /$ $\mathrm{ml}$ penicillin, and $100 \mu \mathrm{g} / \mathrm{ml}$ streptomycin (Sigma, Poole, UK), and confirmed as HPV-16 positive by qPCR and p16 staining. In addition to measuring in the HNSCC cell lines used in the model, DAPK1 promoter methylation was also measured in UPCI-SCC89, UPCI SCC152, UPCI SCC154 [26], and $\mathrm{FaDu}$ [27]; the cervical carcinoma cell lines HeLa [28] and $\mathrm{SiHa}$ [29]; the oral dysplastic epithelial cell line (DOK) [30]; and the basaloid squamous cell carcinoma cell line (PE/CA-PJ34, clone C12) [31]. All cells were cultured at $37^{\circ} \mathrm{C}, 5 \% \mathrm{CO}_{2}$ as per supplier instructions. All cell lines were verified using short tandem repeat (STR) analysis (Public Health England). RPMI cell culture medium contains methyl donors at the following concentrations: L-methionine $101 \mu \mathrm{mol} / \mathrm{L}$, choline chloride $21.4 \mu \mathrm{mol} / \mathrm{L}$, and folic acid $2.26 \mu \mathrm{mol} / \mathrm{L}$; this was designated 'complete medium (100\%)'. RPMI medium containing no L-methionine, choline chloride, or folic acid ( $0 \%$ methyl donors) was custom-made by Gibco ${ }^{\circledR}$ (customisation of \#11875093) and then supplemented with $10 \%(\mathrm{v} / \mathrm{v})$ FBS, $100 \mathrm{IU} / \mathrm{mL}$ penicillin, and $100 \mu \mathrm{g} / \mathrm{mL}$ streptomycin. Complete medium and $0 \%$ medium were mixed in appropriate ratios to produce media containing increasing amounts of methyl donors (e.g., 40, 20, 10, and 5\%) of the complete medium. To avoid a metabolic shock response to depleted medium, cells were gradually depleted of methyl donors over time for 4 days. Cells were then cultured in the experimental methyl donor concentrations for 4 days prior to seeding the cells for the experiments and experiments were performed at the methyl donor concentrations as indicated. The concentration of methyl donors in FBS is minimal [32]; the same batch of FBS was used throughout. For repletion experiments, cells were returned to complete culture media (100\%) after a total of 15 days in depleted conditions and analysed $72 \mathrm{~h}$ later. 


\section{Measurement of methyl donors}

As a marker of disturbance to the methylation cycle, extracellular homocysteine was measured using a highperformance liquid chromatography detection kit (Chromsystems, Gräfelfing, Germany). Cell culture medium was collected and centrifuged to remove cell debris before storage at $-80^{\circ} \mathrm{C}$. Homocysteine concentration was normalised to cell number. Intracellular choline, betaine, and methionine concentrations were determined using isotope dilution liquid chromatography tandem mass spectrometry as previously described [33].

\section{RNA extraction and quantitative RT-PCR}

Total RNA was isolated (Bioline, London, UK) and $700 \mathrm{ng}$ reverse transcribed using High Capacity cDNA Reverse Transcription Kit with RNase Inhibitor. Quantitative PCR was performed using a $7900 \mathrm{HT}$ Fast Real-Time PCR System with thermal cycles of $50^{\circ} \mathrm{C}(2 \mathrm{~min})$ and $95^{\circ} \mathrm{C}$ $(10 \mathrm{~min})$ followed by 40 cycles of $95^{\circ} \mathrm{C}(15 \mathrm{~s})$ and $60^{\circ} \mathrm{C}$ (1 min). For DNMT detection the reaction mix consisted of $300 \mathrm{nM}$ of both forward and reverse primers (Sigma, Poole, UK), $125 \mathrm{nM}$ FAM-labelled probe specific to DNMT 1 , $3 a$ and $3 b$ [34], 2X TaqMan $^{\circledR}$ mastermix, $0.5 \mu \mathrm{L} \beta-2-$ Microglobulin $(\beta 2 \mathrm{M})$ reference control with VIC-reporter dye, and 35 ng cDNA. Inventoried TaqMan ${ }^{\circledR}$ FAMlabelled probes were used to measure expression of DAPKI (Hs00234480_m1), TET1 (Hs00286756_m1) and PUMA (Hs00248075_m1). B-2-Microglobulin (Hs00984230_m1) with a VIC-reporter dye was used as a reference control gene. Relative change in gene expression was calculated using the $2^{-\Delta \Delta \mathrm{Ct}}$ method.

\section{Cell migration}

Cell migration was measured using the Oris ${ }^{\mathrm{TM}}$ cell migration assay (Platypus Technologies, Madison USA). Cells were seeded into 96-well plates and a circular exclusion zone was created using a stopper to prevent cell adherence in the centre of the well as per the manufacturer's guidelines. Once adhered, cells were treated with $0.5 \mu \mathrm{g} / \mathrm{mL}$ mitomycin C (Sigma, Dorset, UK) for $4 \mathrm{~h}$ to inhibit cell division, and the stopper was removed to create an exclusion zone of $5.37 \pm 0.05 \mathrm{~mm}^{2}$ that was imaged using a Spot $^{\mathrm{TM}}$ USB camera (Spot Imaging Solutions, Michigan, USA) at baseline and following cell migration after $72 \mathrm{~h}$.

\section{Cell counts and cell proliferation}

UD-SCC 2 and UPCI-SCC72 cells were detached from tissue culture plates at 24,72 , and $168 \mathrm{~h}$ after seeding and live cells counted on a haemocytometer using trypan blue exclusion. Eighteen counts were performed for each condition and each experiment was performed three times. Cell doubling time was calculated using Doubling Time software (http://www.doubling-time.com). Cell proliferation was measured using CellTrace ${ }^{\mathrm{TM}}$ CFSE Cell Proliferation Kit. Cell suspensions $\left(1 \times 10^{6}\right.$ cells $\left./ \mathrm{mL}\right)$ were incubated with $1 \mu \mathrm{M}$ CSFE CellTrace ${ }^{\mathrm{TM}}$ in PBS/0.1\% BSA for $10 \mathrm{~min}$ at $37^{\circ} \mathrm{C}$, quenched in cold media, incubated for 5 min on ice, washed twice in PBS/0.1\% BSA, and seeded into 6-well plates. The following day, negative cell controls were incubated with mitomycin $\mathrm{C}(0.5 \mu \mathrm{g} / \mathrm{mL})$ for $4 \mathrm{~h}$ at $37^{\circ} \mathrm{C}$ to prevent cell division. At 72 and $168 \mathrm{~h}$, cells were detached, washed, and fixed in $4 \%$ paraformaldehyde. Cell fluorescence intensity was analysed using a $\mathrm{BD}^{\mathrm{TM}}$ LSRII flow cytometer (BD Biosciences, Oxford, UK) and the proliferation index calculated as fluorescence intensity of mitomycin C-treated negative control cells/sample cell fluorescence intensity.

\section{Apoptosis}

Apoptosis analysis was performed using the TACS Annexin V-FITC, Apoptosis Detection Kit, (Trevigen Inc. Gaithersburg, MD, USA). UD-SCC2 and UPCI-SCC72 cells were detached, washed, and incubated with FITC-labelled Annexin $\mathrm{V}$ and propidium iodine immediately prior to analysis. Cell fluorescence was analysed using a $\mathrm{BD}^{\mathrm{TM}}$ LSRII flow cytometer (BD Biosciences). Fluorescence gates were set at the beginning of the experiment using unlabelled and single labelled cells as well as positive controls for necrosis (1\% saponin) and apoptosis $\left(30 \% \mathrm{H}_{2} \mathrm{O}_{2}\right.$ for $10 \mathrm{~min}$ ) (Supplementary Fig. 1). Cells were considered apoptotic if they showed positive staining for Annexin V, necrotic if they were positive for propidium iodine but not Annexin $\mathrm{V}$ and live if negative for both stains.

\section{Immunoblotting of death-associated protein kinase 1 (DAPK1)}

Protein was extracted from cell pellets using ice-cold RIPA buffer with protease and phosphatase inhibitors (Roche Diagnostics Ltd., Sussex, UK), and protein concentration calculated using the bicinchoninic acid assay. Twenty micrograms of protein were separated using Novex ${ }^{\circledR}$ 4-12\% Tris-Glycine gels and transferred to a nitrocellulose membrane by semi-dry transfer. Membranes were blocked with 5\% (w/v) BSA in Tris-buffered saline containing $0.05 \%(\mathrm{v} / \mathrm{v})$ Tween-20 (TBST), and membranes were then incubated with antibodies directed to DAPK1 (clone55; 1:250 dilution; Sigma Aldrich, Poole, UK) or phosphorylated DAPK1 (pSer308; $1 \mu \mathrm{g} / \mathrm{mL}$ dilution; Novus Biologicals, Cambridge, UK) overnight at $4{ }^{\circ} \mathrm{C}$ or with anti- $\beta$-actin (1:30,000; Cell Signalling Technologies ${ }^{\circledR}$, Danvers, MA) 
for $1 \mathrm{~h}$ at room temperature. Membranes were washed and incubated with anti-mouse $\operatorname{IgG}$ horseradish peroxidaseconjugated secondary antibody (1:3000 dilution; Cell Signalling Technologies ${ }^{\circledR}$ ). All antibodies were diluted in 5\% BSA/TBST. Immuno-reactive proteins were visualized using an enhanced chemiluminescent substrate for detection of horseradish peroxidase activity (Pierce ${ }^{\mathrm{TM}}$ ECL Western Blotting Substrate, ThermoFisher).

\section{Genomic DNA isolation, bisulfite modification of DNA, and quantitative methyl-specific PCR}

Genomic DNA was extracted from a panel of cell lines (QIAamp ${ }^{\circledR}$ DNA Mini kit, Qiagen) and $1 \mu \mathrm{g}$ DNA was bisulphite treated using the EZ DNA Methylation ${ }^{\mathrm{TM}}$ kit (Zymo Research, Freiburg, Germany). Methyl-specific qPCR (qMSP) was performed to determine the presence of methylated DAPKI promoter. The reaction mixture comprised of: TaqMan ${ }^{\circledR}$ Universal Mastermix II no UNG, 250 $\mathrm{nM}$ forward and reverse primers, $250 \mathrm{nM}$ FAM-labelled probe with minor groove binding modification [35], and $500 \mathrm{ng}$ bisulphite-treated DNA. $\beta$-actin was used as the reference control gene and amplified as follows: $1 \times \operatorname{TaqMan}^{\circledR}$ Universal Mastermix II no UNG, $900 \mathrm{nM}$ forward and reverse primers, $250 \mathrm{nM}$ VIC-labelled probe, and $100 \mathrm{ng}$ bisulphite treated DNA. A fully methylated DNA control was used as a positive control (Zymo Research Europe, Freiburg, Germany). The following thermal profile was performed: $95^{\circ} \mathrm{C}$ for $10 \mathrm{~min}$, then 50 cycles of $95^{\circ} \mathrm{C}(15 \mathrm{~s})$, $65^{\circ} \mathrm{C}(5 \mathrm{~s})$, and $62.5^{\circ} \mathrm{C}(55 \mathrm{~s})$ using a $7900 \mathrm{HT}$ Fast RealTime PCR System.

\section{Statistical analysis}

Statistical analysis was performed using SPSSv.20 (IBM, Hampshire, UK) and data are expressed as mean \pm standard deviation. All data were tested for homogeneity of variance using Levene's prior to parametric statistical analysis. Pairwise comparisons were conducted using an Independent Student's unpaired $t$ test (Figs. 1, 2, 3b, 4a) and group-wise comparisons were carried out using one-way independent ANOVA with Bonferroni post-hoc comparison (Fig. 3c-e). Differences were considered significant if $p<0.05$.

\section{Results}

\section{Establishment and validation of an in vitro model of methyl donor depletion}

Disturbance to the methyl cycle caused by a deficiency of methyl donors is characterised by an increase in homocysteine concentration; this is well documented as an increase in plasma homocysteine in human studies [36] and in extracellular homocysteine levels in in vitro studies [37]. Figure 1a shows an increase in the extracellular homocysteine of UD-SCC2 after $72 \mathrm{~h}$ of growth in 5\% methyl donor-deficient medium compared with growth in complete medium, and by $168 \mathrm{~h}$, the difference reached statistical significance $(p<0.05)$. Unlike the UD-SCC2 cell line, the UPCI-SCC72 cells were unable to proliferate and survive in culture media containing methyl donor concentrations below $20 \%$ of standard cell culture concentrations. In UPCI-SCC72 cells, an increase in extracellular homocysteine was observed at 72 and $168 \mathrm{~h}$ of growth in $20 \%$ methyl donor medium (Supplementary Fig. 2A). These data confirm a functional disturbance to the methyl cycle in both UD-SCC2 and UPCI-SCC72 cells, validating the methyl donor depletion model. In addition, for UD-SCC 2 cells, the mean intracellular concentration of methionine, choline, and betaine was significantly $(p<0.05)$ decreased by 50,90 , and $85 \%$, respectively after $168 \mathrm{~h}$ in methyl donor deplete (5\%) medium compared to those cultured in control medium (100\%) (Fig. 1b-d). After $72 \mathrm{~h}$ in replete conditions ( $100 \%$ medium), the intracellular concentrations of methionine, choline, and betaine started to increase toward control cell concentrations, although these levels did not reach statistical significance compared to $168 \mathrm{~h}$ depleted cells (Fig. 1b-d).

\section{Methyl donor depletion alters the phenotype of HNSCC cells}

A reduction in methyl donor status in UD-SCC2 cells led to a significant $(p<0.001)$ dose-dependent decrease in cell number compared to $100 \%$ control medium over $168 \mathrm{~h}$ (Fig. 2a). Similar dose-dependent findings were observed for UPCI-SCC72 cells (Supplementary Fig. 2B), although we found these cells to be less tolerant of methyl donor depletion, with concentrations below 20\% causing cell death. In addition, UD-SCC 2 cells grown in complete medium (100\%) displayed a cell-doubling time of $39 \mathrm{~h}$, whereas cells cultured with 10,5 , and $0 \%$ of complete methyl donor concentrations displayed substantially longer cell-doubling times of 86,124 , and $741 \mathrm{~h}$, respectively (Fig. 2b). The same trend was observed for UPCI-SCC72 cells (Supplementary Fig. 2C). The reduction in UD-SCC2 cell-doubling time was, in part, a result of decreased cell proliferation. The proliferation index of deplete cells measured using flow cytometry was significantly $(p<0.005)$ lower than that for control cells after $72 \mathrm{~h}$ and dose-dependent after $168 \mathrm{~h}$ (Fig. 2c). Because change in cell number is affected by both cell proliferation and cell death, we measured cell apoptosis and necrosis after $168 \mathrm{~h}$ depletion. The proportion of cells undergoing apoptosis increased significantly in a dose-dependent manner when 


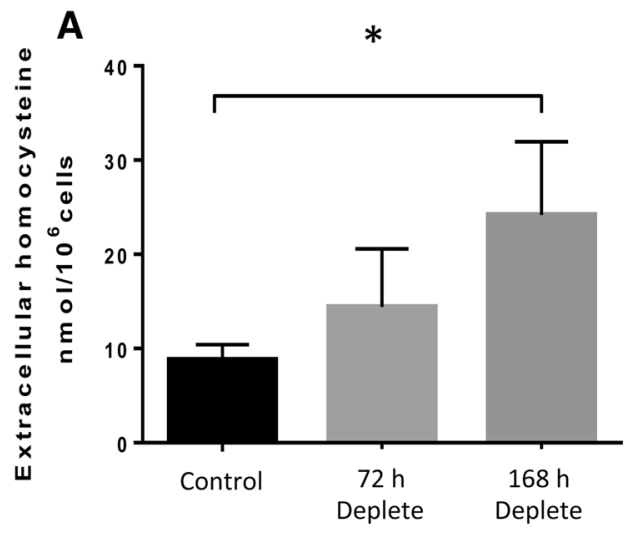

C

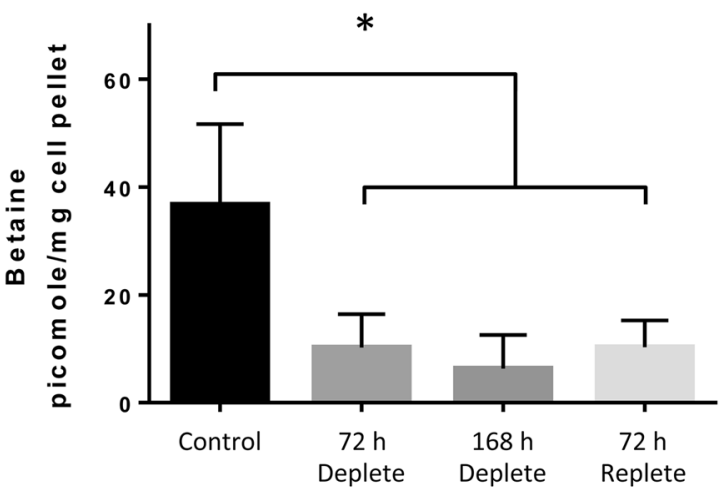

Fig. 1 Validation of methyl donor depletion in UD-SCC2 cells. Disruption to the one carbon metabolism cycle leads to an increase in extracellular homocysteine and loss of intracellular methionine, choline, and betaine. Extracellular homocysteine concentration was measured by HPLC and normalised to cell number. a Concentration of extracellular homocysteine increased in UD-SCC2 cells following 72 and $168 \mathrm{~h}$ culture in depleted (5\%) methyl donor medium com-

cultured with reducing levels of methyl donors in both UDSCC2 (Fig. 2d) and UPCI-SCC72 cells (Supplementary Fig. 2D). Approximately, $15 \%$ of UD-SCC2 cells cultured in methyl donor depleted conditions (5\%) were apoptotic, whereas less than $3 \%$ of the cells cultured in medium containing $100 \%$ methyl donors were apoptotic after $168 \mathrm{~h}$ (Fig. 2d). The proportion of necrotic cells was not affected by methyl donor depletion (Fig. 2d). UD-SCC2 cells cultured in methyl donor depleted medium (5\%) displayed visibly reduced cell motility after $72 \mathrm{~h}$ (Fig. 2e, f). Image analyses showed that cell migration was fourfold lower in methyl donor deplete cells compared to those cultured in complete medium $(p<0.001$; Fig. $2 \mathrm{f})$. This observed difference was due to cell migration and was not a consequence of cell proliferation, because cells were pre-treated with mitomycin $\mathrm{C}$ to inhibit cell division prior to the migration assay. The reduced capacity for cell migration and proliferation was not due to metabolic shock in methyl depleted cells as their metabolism, as determined by MTT assay,
B

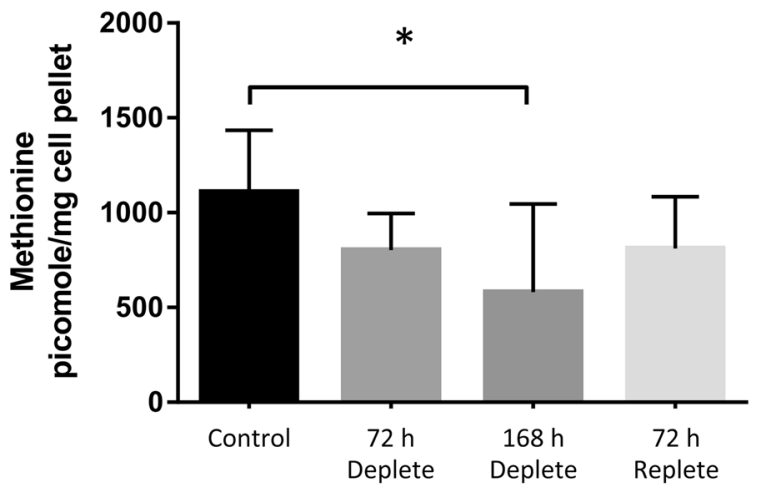

D

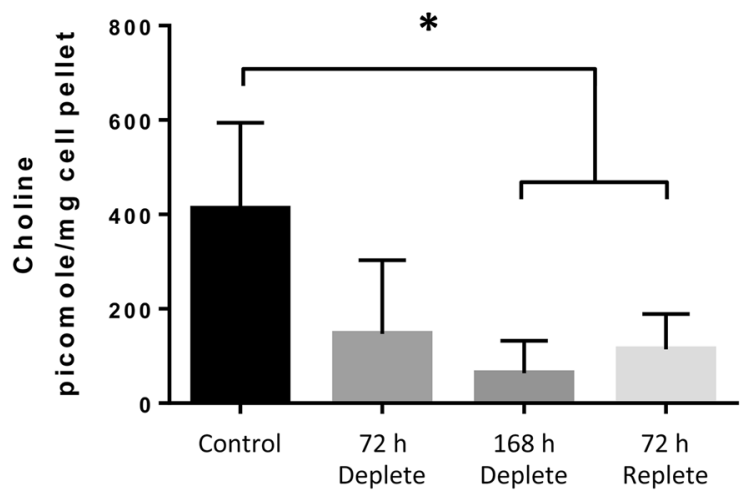

pared to control cells (100\%). The intracellular levels of b methionine, $\mathbf{c}$ betaine, and $\mathbf{d}$ choline, measured by LC-MS/MS were all significantly decreased in UD-SCC2 cells upon methyl donor depletion compared to controls $(* p<0.05)$ and showed signs of recovery after repletion in $100 \%$ methyl donor culture conditions for 72 h. $n=3$ independent experiments performed in triplicate; one-way independent ANOVA with a Bonferroni post-hoc comparison

was not significantly different from control cells (Supplementary Fig. 3a, b).

\section{Methyl donor depletion increases DAPK1 and PUMA expression and affects $D A P K 1$ phosphorylation status in UD-SCC2 cells}

Since methyl donor depletion caused significantly more apoptosis in HPV-positive UD-SCC2 cells compared to HPV-negative UPCI-SCC72 cells, we further examined UD-SCC2 cells for likely mechanisms of increased methyl-donor deplete-induced apoptosis. Gene expression of DAPK1 and PUMA, key enzymes involved in mediating apoptosis and autophagy, was increased fourfold $(p<0.05)$ and 13-fold $(p<0.01)$, respectively, following culture in methyl donor deplete medium (5\%) for $168 \mathrm{~h}$ compared to expression in cells cultured in methyl donor containing (100\%) medium (Fig. 3a, b). This change in expression was completely reversed when cells were cultured in replete 
Fig. 2 Effect of methyl donor depletion on UD-SCC2 cell growth, viability, and migration. a Change in cell number for cells cultured in media containing three different levels of methyl donor depletion $(0,5$ and $10 \%)$ compared to cells grown in control media $(100 \%)$. b Cell doubling time for UD-SCC2 cells cultured in media containing three different levels of methyl donor depletion (10, 5 and $0 \%$ ) compared to cells grown in control media (100\%). c Proliferation of cells cultured in media containing three different levels of methyl donor depletion $(0,5$, and $10 \%$ ), compared to cells grown in control media (100\%) for 72 and $168 \mathrm{~h}$. Higher proliferation index indicates more proliferating cells and increased proliferation rates. $\mathbf{d}$ Proportion of cells undergoing apoptosis (Annexin V positive) or necrosis (PI positive, Annexin V negative) following $168 \mathrm{~h}$ depletion (5\% depletion; $n=4)$ ). $\mathbf{e}$ Cell migration into an exclusion zone (white dotted line on representative images) following $72 \mathrm{~h}$ depletion was compared to cells grown in complete media (100\%). All cells were treated with mitomycin $\mathrm{C}$ prior to use in the migration assay to inhibit cell proliferation. f Area of migration quantified from three independent experiments (independent Student's $t$ test). One-way independent ANOVA with Bonferroni post-hoc comparison; $* p<0.05, * * p<0.01$, ** $p<0.005$

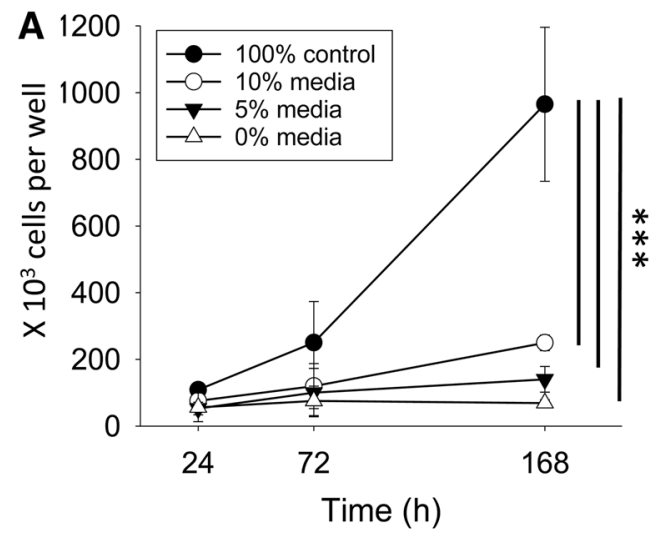

B

\begin{tabular}{|c|c|}
\hline $\begin{array}{c}\text { Methyl Donor } \\
\text { Concentration (\%) }\end{array}$ & $\begin{array}{c}\text { Cell Doubling Time } \\
\text { (h) }\end{array}$ \\
\hline 100 & 39 \\
10 & 86 \\
5 & 124 \\
0 & 741 \\
\hline
\end{tabular}
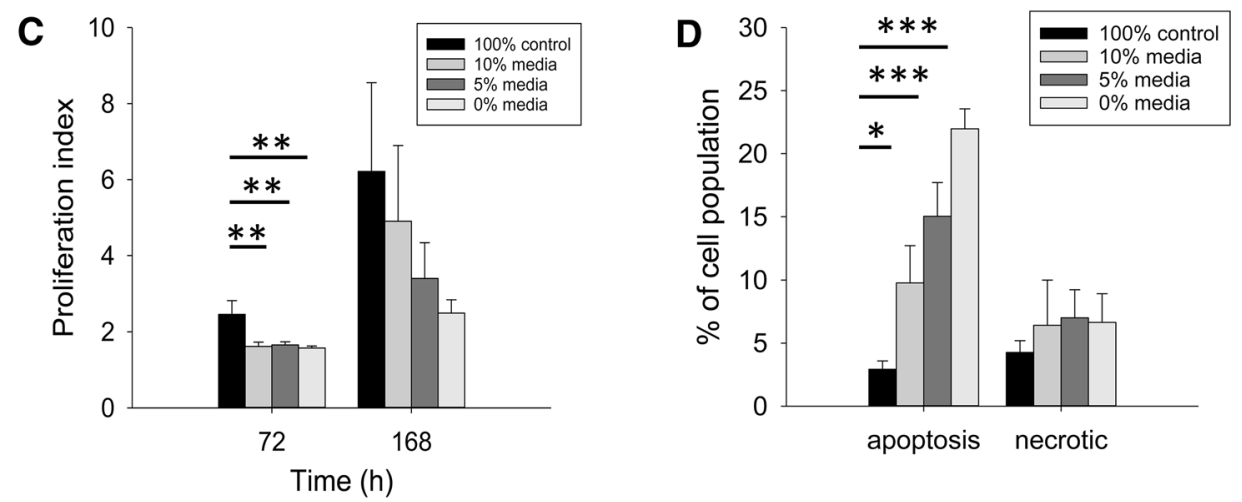

E

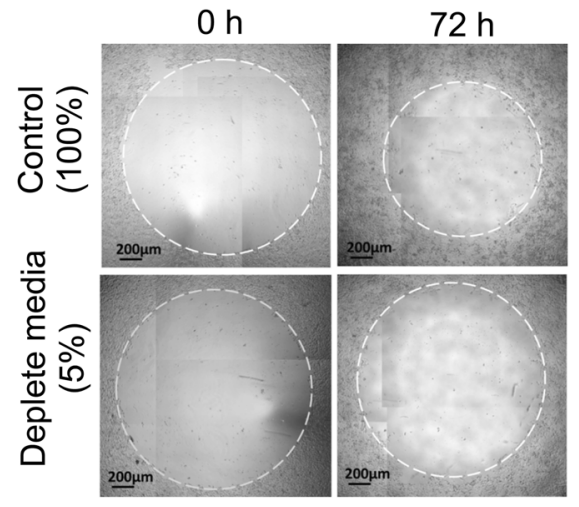

(100\%) methyl donor medium for a further $72 \mathrm{~h}$ (Fig. 3a, b). Levels of total DAPK1 protein expression as well as the phosphorylated, inactive form were measured by immunoblotting. In support of the qPCR data, levels of total DAPK1 protein increased upon methyl donor depletion (5\%) compared to cells cultured in $100 \%$ medium (Fig. 3c). In addition, an immunoblot band corresponding to the phosphorylated, inactive form of DAPK1 was observed in extracts derived from cells cultured in methyl donor containing medium (100\%), whereas phosphorylated DAPK1 (pDAPK1) was absent in lysates from cells cultured in deplete conditions (5\%). When the cells were returned to control media, the level of pDAPK1 returned to control levels demonstrating the effect was reversible (Fig. 3c).

\section{Expression of DNMT $3 a$ and TET1 is increased in methyl donor deplete HPV-positive HNSCC cells}

Expression of DNMT1, the enzyme responsible for maintaining DNA methylation, was not altered in UD-SCC2 cells depleted of methyl donors (5\%) for $168 \mathrm{~h}$ when compared to cells cultured in complete (100\%) medium, or following culture in replete medium for a further $72 \mathrm{~h}$ (Fig. 4a). However, expression of DNMT3a, the enzyme responsible for de novo DNA methylation, was significantly $(p<0.01)$ increased following methyl donor depletion for $168 \mathrm{~h}$ and this change was reversed when these cells were cultured with methyl donor-containing medium, $p<0.01$ (Fig. 4b). A similar trend was also observed for expression 
Fig. 3 Effect of methyl donor depletion on DAPK1 gene expression and protein levels. Gene expression of a $D A P K 1$ and $\mathbf{b} P U M A$ in UD-SCC2 cells measured by qPCR relative to $\beta 2$-microglobulin expression after $168 \mathrm{~h}$ depletion and $72 \mathrm{~h}$ repletion. c Protein expression of total DAPK1 protein and phosphorylated DAPK1 (160 kDa) along with $\beta$-actin loading control (45 $\mathrm{kDa})$ in UD-SCC 2 cells. In a-c, gene and protein expression was measured in UD-SCC2 cells following methyl donor depletion for $168 \mathrm{~h}$ with medium containing 5\% methyl donors (deplete) followed by a further $72 \mathrm{~h}$ culture in medium containing $100 \%$ methyl donors (replete). Control cells were continuously cultured in $100 \%$ methyl donor containing medium alongside deplete and replete cells
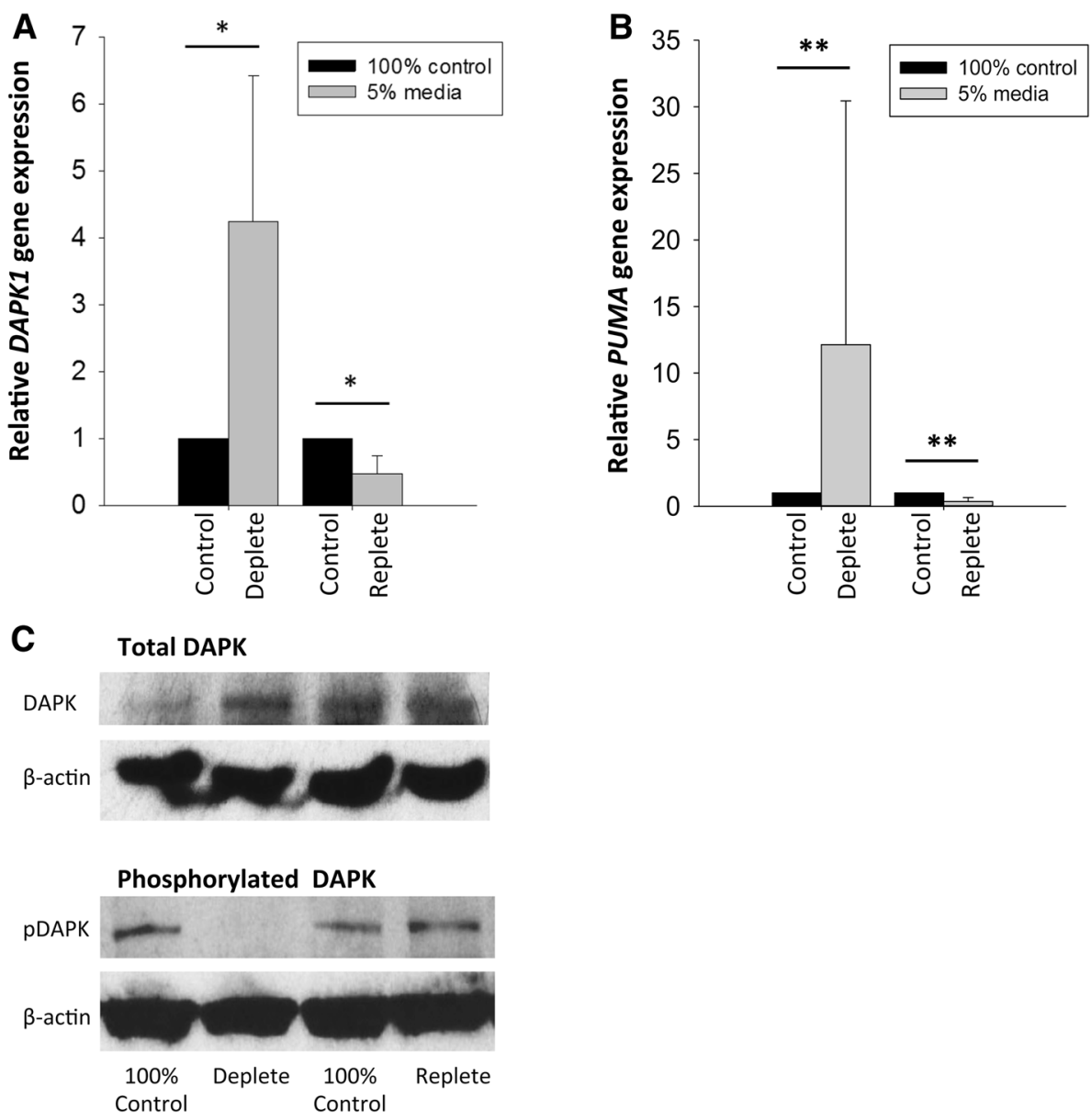

of DNMT3b, although this was not statistically significant (Fig. 4c). In addition, expression of TETI was significantly $(p<0.01)$ increased in UD-SCC2 cells depleted of methyl donors $(5 \%)$ for $168 \mathrm{~h}$ when compared to cells cultured in complete (100\%) medium. Unlike expression of DNMT3a, expression of TET1 remained elevated even after $72 \mathrm{~h}$ culture in replete (100\% methyl donor-containing) medium, but expression was reversed after $168 \mathrm{~h}$ in replete culture conditions (Fig. 3d).

\section{The promoter of DAPK1 is not consistently methylated in HPV-positive HNSCC cells}

Since increased DAPK1 gene methylation has been associated with persistent HPV infection [38] and the promoter region of DAPKl has also been shown to be hypermethylated in HNSCC [18], we investigated the methylation status of the DAPK1 promoter in a panel of six HNSCC cell lines, an oral dysplastic cell line, and a basaloid squamous cell carcinoma cell line (all cultured in methyl donor containing medium). SiHa cervical carcinoma cells were used as methylated DAPKI promoter controls. Of all the HNSCC and dysplastic cell lines tested, only SCC154 displayed a methylated DAPK1 promoter (Fig. 4e).

\section{Discussion}

There is evidence to suggest that altered folate status influences the risk of cancer and there are plausible mechanisms to support this [39, 40]. Studies of methyl donors other than folate have indicated a complex interaction between methyl donor availability and function, whereby deficiency in one methyl donor may be compensated for by another, to maintain a functional methyl cycle [41, 42]. However, very few studies have examined effects of depletion of more than a single methyl donor, where the opportunity for such compensation is minimised. In this study, we successfully developed a model of functional methyl donor deficiency that was characterised by an increased concentration of homocysteine in the extracellular medium and decreased intracellular levels of methyl donors, indicating disturbance to the methyl cycle [36, 37]. The time-related change in extracellular homocysteine was different in the two cell lines used. This may reflect cell-specific sensitivity 

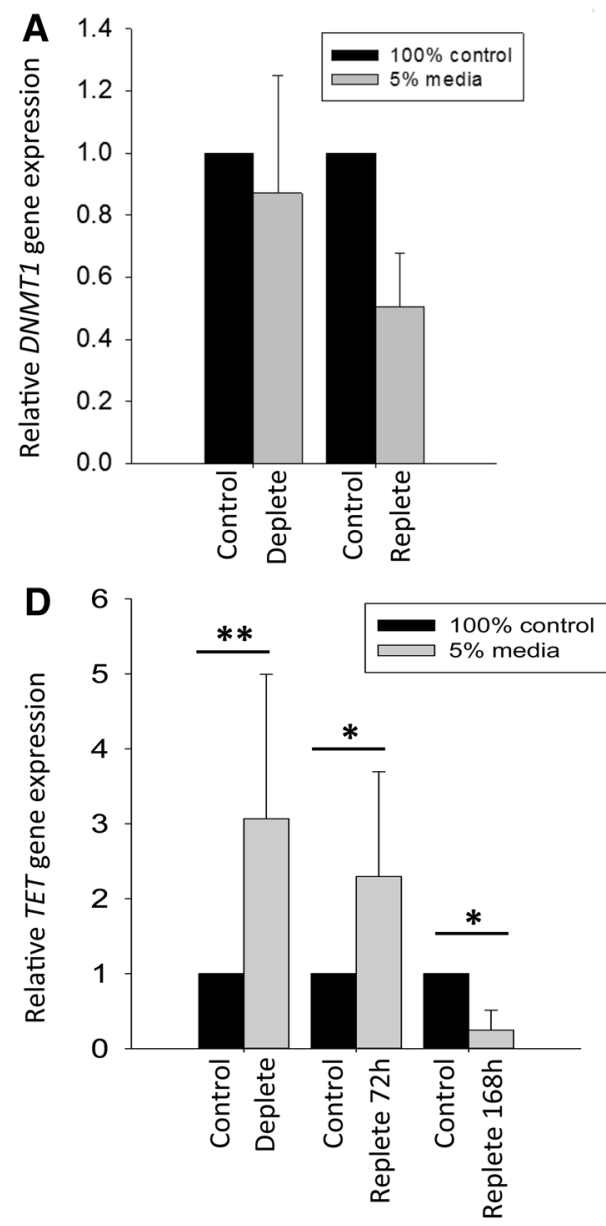
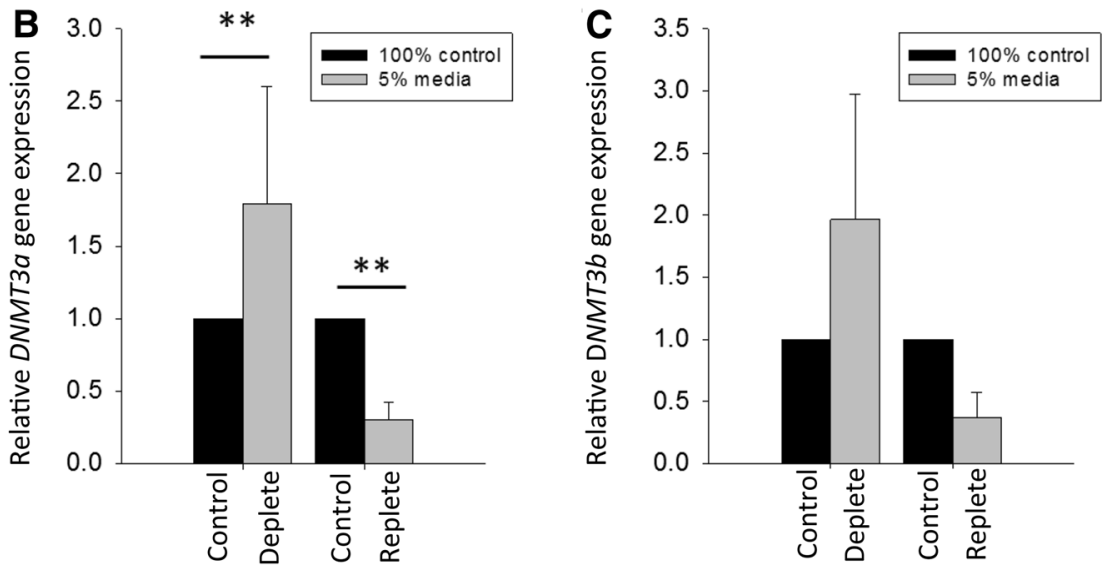

E

\begin{tabular}{|c|c|c|c|c|c|c|c|c|c|c|}
\hline Cell Line & 胥 & 胥 & స్త్ & $\stackrel{N}{N}$ & $\begin{array}{l}\text { o } \\
\text { } \\
\text { }\end{array}$ & $\begin{array}{l}\text { N } \\
\text { กू } \\
\text { Uू }\end{array}$ & 吕 & 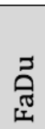 & ํㅡㅇ & 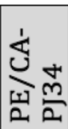 \\
\hline HPV status & + & + & + & - & - & + & + & - & - & - \\
\hline $\begin{array}{l}\text { Methylated DAPK1 } \\
\text { expression }\end{array}$ & + & - & - & - & - & - & + & - & - & - \\
\hline
\end{tabular}

Fig. 4 Effect of methyl donor depletion and repletion on DNMT and TET1 expression. Gene expression of DNMT1 (a), DNMT3a (b), and $D N M T 3 b(\mathbf{c})$ and $\mathbf{d}$ TET1 relative to $\beta 2 \mathrm{M}$ expression was measured using qPCR in UD-SCC2 cells. Expression was measured following methyl donor depletion for $168 \mathrm{~h}$ with medium containing 5\% methyl donors (deplete) followed by a further $72 \mathrm{~h}$ culture in medium containing $100 \%$ methyl donors (and $168 \mathrm{~h}$ for TET1) (replete). Control cells were continuously cultured in $100 \%$ methyl donor containing

to methyl donor depletion, including differential up-regulation of folate receptors and/or homocysteine metabolism $[43,44]$.

Cancer cell motility is important for tumour cell invasion during HNSCC progression and subsequently leads to the development of local or distant site metastases. Our data demonstrate for the first time that HNSCC cell migration is significantly impaired in methyl donor depleted conditions. Moreover, the cellular response is unlikely to be due to metabolic shock as the metabolic status of deplete and control cells was similar. This is an important finding as increased cell migration has been associated with poor prognosis in HNSCC [45] and the ability to immobilise cancer cells is an important target for cancer drug development. There has been relatively little research into the medium alongside deplete and replete cells. $n=6$, independent Student's $t$ test, ${ }^{* *} p<0.01$. e Presence of methylated DAPK1 promoter in a panel of HNSCC cell lines as measured by qMSP; the cervical cell lines $\mathrm{SiHa}$ were used as controls. Table shows cells positive for $D A P K 1$ methylation $(+, \mathrm{Ct}$ values $<35)$ and cells negative for methylated $D A P K 1(-, \mathrm{Ct}$ values $>35)$. All cell lines tested were positive for $\beta$-actin (mean Ct value $25 \pm 0.47$ )

effects of methyl donor depletion on tumour cell migration and findings suggest that effects may be cell specific. Human HCT116 colon carcinoma cells showed increased migration in folate-deplete conditions [46], whereas Graziosi et al. reported reduced cell migration in methioninedepleted gastric cancer cells [47]. The effects on migration may be mediated by epigenetic alterations in the expression of genes important for cell locomotion. The actin cytoskeleton plays a central role in cell movement and studies on the effects of methyl donor depletion in various cell types suggest that genes associated with the regulation of the actin cytoskeleton are invariably down regulated. Duthie et al. reported reduced expression of proteins important for cytoskeleton organization in folate-depleted human colonocytes [8], whilst Jhaveri et al. showed down-regulation of 
cytoskeleton 14 in folate-depleted human $\mathrm{KB}$ (HeLa) cells [48].

The observed reduction in cell proliferation in methyldonor deplete UD-SCC2 cells could, in part, be explained by a shortage of purine and pyrimidines that are essential for DNA production, as methyl donors are required for the synthesis of these molecules. An alternative explanation may be that methyl donor-depleted cells are arrested at G1 in the cell cycle, as has previously been reported in human and murine B cells with reduced levels of methionine and SAM [49]. The effect on cell proliferation observed in this study was dose-dependent and the rate of cell proliferation was restored following repletion. The decrease in cell proliferation rate detected in methyl donor-deficient cultures did not account entirely for the reduction in cell number observed. Cell death, through apoptosis, also increased in the methyl donor depleted conditions, while cell necrosis remained unchanged.

The role that folate plays in DNA synthesis and cell division is well understood and this is the basis for the use of anti-folate drugs in cancer treatment. A decrease in methyl donor availability is expected to lead to a fall in cell proliferation and this is what we observed. Evidence linking folate status with apoptosis is limited and inconsistent [50-52]. An increase in apoptosis is understood to have beneficial effects in cancer and a low level of apoptosis in HNSCC is associated with poor prognosis [53]. Low availability of methyl donors, in particular folate, may lead to reduced DNA synthesis and thus inhibit tumour cell proliferation of established tumours.

$D A P K 1$ and PUMA are pro-apoptotic genes known to be up-regulated when cells encounter stress $[54,55]$. We hypothesised that activation of pro-apoptotic genes mediates the increase in apoptosis observed in methyl donor depleted cells. DAPKI and PUMA mRNA levels significantly increased following methyl donor depletion and, in the case of DAPK1, this was associated with an increase in protein levels as well, a response that was reversed upon methyl donor repletion. Interestingly, cells that were methyl donor deficient also displayed reduced levels of phosphorylated DAPK1, the inactive form of the protein, compared to cells cultured in complete media. These data suggest that upon prolonged methyl donor depletion, cells respond by not only increasing the gene expression of DAPKI but also by increasing the active, non-phosphorylated form of the protein that then drives the pro-apoptotic pathway leading to the programmed cell death of HNSCC cells.

A functionally impaired methyl cycle was associated with effects on the expression of DNMTs and TET1. The expression of DNMT1, the DNMT involved in maintaining DNA methylation status following cell division [19], was not influenced by a reduction in methyl donor status in UD-SCC2 cells. Reports of effects of folate depletion on DNMT1 expression in cultured cells are inconsistent; Stempak et al., [56] reported a down-regulation in mouse fibroblasts and human colon cancer cells, whilst Hayashi et al. [32] observed an up-regulation in response to folate depletion of the same human colon cancer cells. In contrast to DNMT1, expression of DNMT3a was increased in methyl donor deplete UD-SCC2 cells and this effect was reversed upon methyl donor repletion. A similar direction of change was seen for DNMT3b, although the effect was not statistically significant. Others have reported an increase in the expression of DNMT3a in response to methyl donor depletion in animal models and the relative resistance of DNMT3b to methyl donor depletion has also been documented in these studies [57, 58]. However, colon cancer cells depleted of folate alone are reported to show a decrease in DNMT3a $[32,56]$, and Poomipark et al. reported a decrease in DNMT3a and DNMT3b in a folate and methionine-depleted cervical cancer cell line C4II [22], adding to the evident inconsistency of response to single or multiple methyl donor depletion in different experimental systems. The fact that we were able to demonstrate reversibility of the effect on DNMT3a expression is a strong indicator of the causal relationship between methyl donor availability and DNMT3a expression in HNSCC cells. It is plausible that in methyl donor deplete HNSCC cells, expression of DNMT3a and TETI (responsible for DNA demethylation) is increased as an adaptive response, to scavenge cellular sources of methyl groups and maintain epigenetic control of gene transcription. Deletion of DNMT3a has been shown to promote lung tumour progression [59] and expression has been shown to be higher in leukaemia compared with control cells [60]. Sun et al. recently showed that inhibition of DNMT3a in cervical cancer cells induced apoptosis, suggesting a cancer promoting effect of DNMT3a [61]. In our study, increased expression of DNMT3a and TET1 was associated with increased apoptosis; whether these responses to methyl donor depletion are causally linked is not clear.

Methylation of both host and viral DNA is thought to be important in HPV-positive cancers, with distinct methylation patterns observed in HPV-positive and negative disease [62]. It has previously been shown that the $D A P K 1$ promoter is hyper-methylated in oral cancer cells and the prevalence of DAPK1 methylation in oral cancer ranges from 7 to $68 \%$ [18]. This led us to hypothesise that in methyl donor deplete conditions, the lack of readily available methyl groups would result in loss of methylation within the DAPK1 promoter, leading to increased $D A P K 1$ gene expression, increased protein production and activity, and, therefore, increased apoptosis. The previous studies have shown variations in gene methylation patterns following folate depletion in vitro depending on the cell type and gene of interest [39]. However, we found that the 
DAPK1 promoter was not methylated in UD-SCC2 HPVpositive cells or in several other HNSCC/dysplastic (HPVnegative) cell lines. This was not due to a lack of specificity of the PCR primers used as SiHa cervical carcinoma cells displayed methylated $D A P K 1$ as previously described [63]. These data suggest that other mechanisms regulating $D A P K 1$ gene expression and activation are at play in these cells or that the DAPK1 gene is under epigenetic control at other sites within the promoter region that were not covered by our primer sequences.

The evidence presented from this study indicates that methyl donor depletion of HNSCC cell lines results in a less aggressive cancer cell phenotype. Cancer cells which display reduced proliferation, increased apoptosis, and decreased migration are highly likely to produce less aggressive tumours in vivo. While low folate consumption is considered to be a risk factor for cancer at various sites, this may not be true for established cancers or in cells that contain microscopic neoplastic foci where folate could promote rather than prevent carcinogenesis through the provision of nucleotide precursors required for growth of rapidly dividing cancer cells $[64,65]$. Indeed, there is increasing evidence from studies in animals and humans to suggest that whilst adequate folate status may be protective against cancer initiation, folate deficiency can slow cancer growth, whilst high intakes may enhance growth of certain cancers, including colorectal, breast, and prostate cancer [64-66]. Recent evidence extends this observation to other nutrients involved in the methyl cycle [67].

This study has demonstrated that depleting HNSCC cells of methyl donors has beneficial effects in terms of the cancer phenotype and provides mechanistic data to support evidence suggesting that high intakes of methyl donors may have adverse effects in established cancers or where precancerous lesions exist.

Acknowledgements The authors thank Prof. Sheila Innis and Mr. Roger Dyer (University of British Columbia) for methyl donor analysis, Mrs. Marilyn Hill (University of Sheffield) for performing HPLC analysis, and Mrs. Brenka McCabe (University of Sheffield) for additional qPCR analysis. The authors have no conflict of interest. This work was funded by World Cancer Research Fund (WCRF, UK), as part of the World Cancer Research Fund International grant programme (Grant Number 2012/587) and SimplyHealth, USA.

\section{Compliance with ethical standards}

Conflict of interest The authors declare no conflict of interest.

Open Access This article is distributed under the terms of the Creative Commons Attribution 4.0 International License (http:// creativecommons.org/licenses/by/4.0/), which permits unrestricted use, distribution, and reproduction in any medium, provided you give appropriate credit to the original author(s) and the source, provide a link to the Creative Commons license, and indicate if changes were made.

\section{References}

1. Ferlay J, Soerjomataram I, Dikshit R, Eser S, Mathers C, Rebelo M, Parkin DM, Forman D, Bray F (2012) GLOBOCAN 2012 v1.0, Cancer Incidence and Mortality Worldwide: IARC CancerBase No. 11. Available via NLM. 2016

2. Gatta G, Botta L, Sánchez MJ, Anderson LA, Pierannunzio D, Licitra L, Group EW (2015) Prognoses and improvement for head and neck cancers diagnosed in Europe in early 2000s: the EUROCARE-5 population-based study. Eur J Cancer. doi:10.1016/j.ejca.2015.07.043

3. Napier SS, Speight PM (2008) Natural history of potentially malignant oral lesions and conditions: an overview of the literature. $\mathrm{J}$ Oral Pathol Med 37(1):1-10. doi:10.1111/j.1600-0714.2007.00579.x

4. Kreimer AR, Clifford GM, Boyle P, Franceschi S (2005) Human papillomavirus types in head and neck squamous cell carcinomas worldwide: a systematic review. Cancer Epidemiol Biomark Prev 14(2):467-475. doi:10.1158/1055-9965.EPI-04-0551

5. Chaturvedi AK, Engels EA, Pfeiffer RM, Hernandez BY, Xiao W, Kim E, Jiang B, Goodman MT, Sibug-Saber M, Cozen W, Liu L, Lynch CF, Wentzensen N, Jordan RC, Altekruse S, Anderson WF, Rosenberg PS, Gillison ML (2011) Human papillomavirus and rising oropharyngeal cancer incidence in the United States. J Clin Oncol 29(32):4294-4301. doi:10.1200/ JCO.2011.36.4596

6. Blount BC, Mack MM, Wehr CM, MacGregor JT, Hiatt RA, Wang G, Wickramasinghe SN, Everson RB, Ames BN (1997) Folate deficiency causes uracil misincorporation into human DNA and chromosome breakage: implications for cancer and neuronal damage. Proc Nat Acad Sci USA 94 (7):3290-3295

7. Titenko-Holland N, Jacob RA, Shang N, Balaraman A, Smith MT (1998) Micronuclei in lymphocytes and exfoliated buccal cells of postmenopausal women with dietary changes in folate. Mutat Res 417(2-3):101-114

8. Duthie SJ, Mavrommatis Y, Rucklidge G, Reid M, Duncan G, Moyer MP, Pirie LP, Bestwick CS (2008) The response of human colonocytes to folate deficiency in vitro: functional and proteomic analyses. J Proteome Res 7(8):3254-3266. doi:10.1021/ pr700751y

9. Freedman ND, Park Y, Subar AF, Hollenbeck AR, Leitzmann MF, Schatzkin A, Abnet CC (2008) Fruit and vegetable intake and head and neck cancer risk in a large United States prospective cohort study. Int J Cancer 122(10):2330-2336. doi:10.1002/ ijc. 23319

10. Kune GA, Kune S, Field B, Watson LF, Cleland H, Merenstein D, Vitetta L (1993) Oral and pharyngeal cancer, diet, smoking, alcohol, and serum vitamin A and beta-carotene levels: a case-control study in men. Nutr Cancer 20(1):61-70. doi:10.1080/01635589309514271

11. Pelucchi C, Talamini R, Negri E, Levi F, Conti E, Franceschi S, La Vecchia C (2003) Folate intake and risk of oral and pharyngeal cancer. Ann Oncol 14(11):1677-1681

12. Petersen LF, Brockton NT, Bakkar A, Liu S, Wen J, Weljie AM, Bismar TA (2012) Elevated physiological levels of folic acid can increase in vitro growth and invasiveness of prostate cancer cells. BJU Int 109(5):788-795. doi:10.1111/j.1464-410X.2011.10437.x

13. Ly A, Lee H, Chen J, Sie KK, Renlund R, Medline A, Sohn KJ, Croxford R, Thompson LU, Kim YI (2011) Effect of maternal and postweaning folic acid supplementation on mammary tumor risk in the offspring. Cancer Res 71(3):988-997. doi:10.1158/0008-5472.CAN-10-2379

14. Piyathilake CJ, Henao OL, Macaluso M, Cornwell PE, Meleth S, Heimburger DC, Partridge EE (2004) Folate is associated 
with the natural history of high-risk human papillomaviruses. Cancer Res 64(23):8788-8793. doi:10.1158/0008-5472. can-04-2402

15. Flatley JE, McNeir K, Balasubramani L, Tidy J, Stuart EL, Young TA, Powers HJ (2009) Folate status and aberrant DNA methylation are associated with HPV infection and cervical pathogenesis. Cancer Epidemiol Biomark Prev 18(10):27822789. doi:10.1158/1055-9965.EPI-09-0493

16. Xiao S, Tang YS, Khan RA, Zhang Y, Kusumanchi P, Stabler SP, Jayaram HN, Antony AC (2012) Influence of physiologic folate deficiency on human papillomavirus type 16 (HPV16)harboring human keratinocytes in vitro and in vivo. J Biol Chem 287(15):12559-12577. doi:10.1074/jbc.M111.317040

17. Towle R, Truong D, Hogg K, Robinson WP, Poh CF, Garnis C (2013) Global analysis of DNA methylation changes during progression of oral cancer. Oral Oncol 49(11):1033-1042. doi:10.1016/j.oraloncology.2013.08.005

18. Ha PK, Califano JA (2006) Promoter methylation and inactivation of tumour-suppressor genes in oral squamouscell carcinoma. Lancet Oncol 7(1):77-82. doi:10.1016/ S1470-2045(05)70540-4

19. Bestor T, Laudano A, Mattaliano R, Ingram V (1988) Cloning and sequencing of a cDNA encoding DNA methyltransferase of mouse cells. The carboxyl-terminal domain of the mammalian enzymes is related to bacterial restriction methyltransferases. J Mol Biol 203(4):971-983

20. Okano M, Bell DW, Haber DA, Li E (1999) DNA methyltransferases Dnmt3a and Dnmt3b are essential for de novo methylation and mammalian development. Cell 99(3):247-257

21. Ito S, Shen L, Dai Q, Wu SC, Collins LB, Swenberg JA, He C, Zhang Y (2011) Tet proteins can convert 5-methylcytosine to 5-formylcytosine and 5-carboxylcytosine. Science 333(6047):1300-1303. doi:10.1126/science.1210597

22. Poomipark N, Flatley JE, Hill MH, Mangnall B, Azar E, Grabowski P, Powers HJ (2016) Methyl donor status influences DNMT expression and global DNA methylation in cervical cancer cells. Asian Pac J Cancer Prev 17(7):3213-3222

23. Lin Y, Hupp TR, Stevens C (2010) Death-associated protein kinase (DAPK) and signal transduction: additional roles beyond cell death. FEBS J 277(1):48-57. doi:10.1111/j.1742-4658.2009.07411.x

24. Altman BJ, Rathmell JC (2012) Metabolic stress in autophagy and cell death pathways. Cold Spring Harb Perspect Biol 4(9):a008763. doi:10.1101/cshperspect.a008763

25. Hoffmann TK, Sonkoly E, Hauser U, van Lierop A, Whiteside TL, Klussmann JP, Hafner D, Schuler P, Friebe-Hoffmann U, Scheckenbach K, Erjala K, Grénman R, Schipper J, Bier H, Balz $\mathrm{V}$ (2008) Alterations in the p53 pathway and their association with radio- and chemosensitivity in head and neck squamous cell carcinoma. Oral Oncol 44(12):1100-1109. doi:10.1016/j. oraloncology.2008.02.006

26. White JS, Weissfeld JL, Ragin CC, Rossie KM, Martin CL, Shuster M, Ishwad CS, Law JC, Myers EN, Johnson JT, Gollin SM (2007) The influence of clinical and demographic risk factors on the establishment of head and neck squamous cell carcinoma cell lines. Oral Oncol 43(7):701-712. doi:10.1016/j. oraloncology.2006.09.001

27. Rangan SR (1972) A new human cell line $(\mathrm{FaDu})$ from a hypopharyngeal carcinoma. Cancer 29(1):117-121

28. Scherer WF, Syverton JT, Gey GO (1953) Studies on the propagation in vitro of poliomyelitis viruses. IV. Viral multiplication in a stable strain of human malignant epithelial cells (strain $\mathrm{HeLa}$ ) derived from an epidermoid carcinoma of the cervix. J Exp Med 97(5):695-710

29. Friedl F, Kimura I, Osato T, Ito Y (1970) Studies on a new human cell line ( $\mathrm{SiHa}$ ) derived from carcinoma of uterus. I.
Its establishment and morphology. Proc Soc Exp Biol Med 135(2):543-545

30. Chang SE, Foster S, Betts D, Marnock WE (1992) DOK, a cell line established from human dysplastic oral mucosa, shows a partially transformed non-malignant phenotype. Int J Cancer 52(6):896-902

31. Berndt A, Hyckel P, Könneker A, Katenkamp D, Kosmehl H (1997) Oral squamous cell carcinoma invasion is associated with a laminin-5 matrix re-organization but independent of basement membrane and hemidesmosome formation. Clues from an in vitro invasion model. Invasion Metastasis 17(5):251-258

32. Hayashi I, Sohn KJ, Stempak JM, Croxford R, Kim YI (2007) Folate deficiency induces cell-specific changes in the steadystate transcript levels of genes involved in folate metabolism and 1-carbon transfer reactions in human colonic epithelial cells. J Nutr 137(3):607-613

33. Friesen RW, Novak EM, Hasman D, Innis SM (2007) Relationship of dimethylglycine, choline, and betaine with oxoproline in plasma of pregnant women and their newborn infants. J Nutr 137(12):2641-2646

34. Balada E, Ordi-Ros J, Serrano-Acedo S, Martinez-Lostao L, Rosa-Leyva M, Vilardell-Tarres M (2008) Transcript levels of DNA methyltransferases DNMT1, DNMT3A and DNMT3B in CD4 $+\mathrm{T}$ cells from patients with systemic lupus erythematosus. Immunol 124 (3):339-347. doi:10.1111/j.1365-2567.2007.02771.x

35. Nikolaidis G, Raji OY, Markopoulou S, Gosney JR, Bryan J, Warburton C, Walshaw M, Sheard J, Field JK, Liloglou T (2012) DNA methylation biomarkers offer improved diagnostic efficiency in lung cancer. Cancer Res 72(22):5692-5701. doi:10.1158/0008-5472.CAN-12-2309

36. Moat SJ, Hill MH, McDowell IF, Pullin CH, Ashfield-Watt PA, Clark ZE, Whiting JM, Newcombe RG, Lewis MJ, Powers HJ (2003) Reduction in plasma total homocysteine through increasing folate intake in healthy individuals is not associated with changes in measures of antioxidant activity or oxidant damage. Eur J Clin Nutr 57(3):483-489. doi:10.1038/ sj.ejen. 1601554

37. Nakano E, Taiwo FA, Nugent D, Griffiths HR, Aldred S, Paisi M, Kwok M, Bhatt P, Hill MH, Moat S, Powers HJ (2005) Downstream effects on human low density lipoprotein of homocysteine exported from endothelial cells in an in vitro system. $\mathbf{J}$ Lipid Res 46(3):484-493. doi:10.1194/jlr.M400339-JLR200

38. Flatley JE, Sargent A, Kitchener HC, Russell JM, Powers HJ (2014) Tumour suppressor gene methylation and cervical cell folate concentration are determinants of high-risk human papillomavirus persistence: a nested case control study. BMC Cancer 14:803. doi:10.1186/1471-2407-14-803

39. Duthie SJ (2011) Folate and cancer: how DNA damage, repair and methylation impact on colon carcinogenesis. J Inherit Metab Dis 34(1):101-109. doi: $10.1007 / \mathrm{s} 10545-010-9128-0$

40. Ulrich CM, Potter JD (2007) Folate and cancer-timing is everything. JAMA 297(21):2408-2409. doi:10.1001/ jama.297.21.2408

41. Niculescu MD, Zeisel SH (2002) Diet, methyl donors and DNA methylation: interactions between dietary folate, methionine and choline. J Nutr 132(8 Suppl):2333S-2335S

42. Shin W, Yan J, Abratte CM, Vermeylen F, Caudill MA (2010) Choline intake exceeding current dietary recommendations preserves markers of cellular methylation in a genetic subgroup of folate-compromised men. J Nutr 140(5):975-980. doi:10.3945/ jn. 110.121186

43. Doucette MM, Stevens VL (2001) Folate receptor function is regulated in response to different cellular growth rates in cultured mammalian cells. J Nutr 131(11):2819-2825 
44. Hultberg B (2003) Modulation of extracellular homocysteine concentration in human cell lines. Clin Chim Acta 330(1-2):151-159

45. Lyons AJ, Jones J (2007) Cell adhesion molecules, the extracellular matrix and oral squamous carcinoma. Int J Oral Maxillofac Surg 36(8):671-679. doi:10.1016/j.ijom.2007.04.002

46. Wang TP, Hsu SH, Feng HC, Huang RF (2012) Folate deprivation enhances invasiveness of human colon cancer cells mediated by activation of sonic hedgehog signaling through promoter hypomethylation and cross action with transcription nuclear factor-kappa B pathway. Carcinogenesis 33(6):1158-1168. doi:10.1093/carcin/bgs138

47. Graziosi L, Mencarelli A, Renga B, D’Amore C, Bruno A, Santorelli C, Cavazzoni E, Cantarella F, Rosati E, Donini A, Fiorucci S (2013) Epigenetic modulation by methionine deficiency attenuates the potential for gastric cancer cell dissemination. J Gastrointest Surg 17 (1):39-49. doi:10.1007/s11605-0121996-1(discussion p. 49)

48. Jhaveri MS, Wagner C, Trepel JB (2001) Impact of extracellular folate levels on global gene expression. Mol Pharmacol 60(6):1288-1295

49. Lin DW, Chung BP, Kaiser P (2014) S-adenosylmethionine limitation induces $\mathrm{p} 38$ mitogen-activated protein kinase and triggers cell cycle arrest in G1. J Cell Sci 127(Pt 1):50-59. doi:10.1242/ jes. 127811

50. Garcia-Crespo D, Knock E, Jabado N, Rozen R (2009) Intestinal neoplasia induced by low dietary folate is associated with altered tumor expression profiles and decreased apoptosis in mouse normal intestine. J Nutr 139(3):488-494. doi:10.3945/ jn.108.095661

51. Cao DZ, Sun WH, Ou XL, Yu Q, Yu T, Zhang YZ, Wu ZY, Xue QP, Cheng YL (2005) Effects of folic acid on epithelial apoptosis and expression of Bcl-2 and p53 in premalignant gastric lesions. World J Gastroenterol 11(11):1571-1576

52. Hsu HC, Chiou JF, Wang YH, Chen CH, Mau SY, Ho CT, Chang PJ, Liu TZ (2013) Folate deficiency triggers an oxidative-nitrosative stress-mediated apoptotic cell death and impedes insulin biosynthesis in RINm5F pancreatic islet $\beta$-cells: relevant to the pathogenesis of diabetes. PLoS One 8(11):e77931. doi:10.1371/ journal.pone.0077931

53. Xie X, Clausen OP, De Angelis P, Boysen M (1999) The prognostic value of spontaneous apoptosis, Bax, Bcl-2, and p53 in oral squamous cell carcinoma of the tongue. Cancer 86(6):913-920

54. Deiss LP, Feinstein E, Berissi H, Cohen O, Kimchi A (1995) Identification of a novel serine/threonine kinase and a novel $15-\mathrm{kD}$ protein as potential mediators of the gamma interferoninduced cell death. Genes Dev 9(1):15-30

55. Nakano K, Vousden KH (2001) PUMA, a novel proapoptotic gene, is induced by p53. Mol Cell 7(3):683-694

56. Stempak JM, Sohn KJ, Chiang EP, Shane B, Kim YI (2005) Cell and stage of transformation-specific effects of folate deficiency on methionine cycle intermediates and DNA methylation in an in vitro model. Carcinogenesis 26(5):981-990. doi:10.1093/ carcin/bgi037

57. Ghoshal K, Li X, Datta J, Bai S, Pogribny I, Pogribny M, Huang Y, Young D, Jacob ST (2006) A folate- and methyl-deficient diet alters the expression of DNA methyltransferases and methyl CpG binding proteins involved in epigenetic gene silencing in livers of F344 rats. J Nutr 136(6):1522-1527

58. Kovacheva VP, Mellott TJ, Davison JM, Wagner N, LopezCoviella I, Schnitzler AC, Blusztajn JK (2007) Gestational choline deficiency causes global and Igf2 gene DNA hypermethylation by up-regulation of Dnmt1 expression. J Biol Chem 282(43):31777-31788. doi:10.1074/jbc.M705539200

59. Gao Q, Steine EJ, Barrasa MI, Hockemeyer D, Pawlak M, Fu D, Reddy S, Bell GW, Jaenisch R (2011) Deletion of the de novo DNA methyltransferase Dnmt3a promotes lung tumor progression. Proc Natl Acad Sci USA 108(44):18061-18066. doi:10.1073/pnas.1114946108

60. Mizuno S, Chijiwa T, Okamura T, Akashi K, Fukumaki Y, Niho Y, Sasaki H (2001) Expression of DNA methyltransferases DNMT1, $3 \mathrm{~A}$, and 3B in normal hematopoiesis and in acute and chronic myelogenous leukemia. Blood 97(5):1172-1179

61. Sun J, Ji J, Huo G, Song Q, Zhang X (2015) miR-182 induces cervical cancer cell apoptosis through inhibiting the expression of DNMT3a. Int J Clin Exp Pathol 8(5):4755-4763

62. van Kempen PM, Noorlag R, Braunius WW, Stegeman I, Willems SM, Grolman W (2014) Differences in methylation profiles between HPV-positive and HPV-negative oropharynx squamous cell carcinoma: a systematic review. Epigenetics 9(2):194-203. doi:10.4161/epi.26881

63. Leung RC, Liu SS, Chan KY, Tam KF, Chan KL, Wong LC, Ngan HY (2008) Promoter methylation of death-associated protein kinase and its role in irradiation response in cervical cancer. Oncol Rep 19(5):1339-1345

64. Kim YI (2006) Folate: a magic bullet or a double edged sword for colorectal cancer prevention? Gut 55(10):1387-1389. doi:10.1136/gut.2006.095463

65. Bistulfi G, Foster BA, Karasik E, Gillard B, Miecznikowski J, Dhiman VK, Smiraglia DJ (2011) Dietary folate deficiency blocks prostate cancer progression in the TRAMP model. Cancer Prev Res (Phila) 4(11):1825-1834. doi:10.1158/1940-6207. CAPR-11-0140

66. Deghan Manshadi S, Ishiguro L, Sohn KJ, Medline A, Renlund R, Croxford R, Kim YI (2014) Folic acid supplementation promotes mammary tumor progression in a rat model. PLoS One 9(1):e84635. doi:10.1371/journal.pone.0084635

67. Kadaveru K, Protiva P, Greenspan EJ, Kim YI, Rosenberg DW (2012) Dietary methyl donor depletion protects against intestinal tumorigenesis in Apc(Min/+) mice. Cancer Prev Res (Phila) 5(7):911-920. doi:10.1158/1940-6207.CAPR-11-0544 